\title{
DAMPAK PENINGKATAN ASSET, PROFITABILITAS DAN LIKUIDITAS TERHADAP LEVERAGE PERUSAHAAN
}

\author{
Indra Widjaja \\ Program Studi Magister Manajemen (MM) Universitas Tarumanagara Jakarta \\ Email: (indraw9392@gmail.com).
}

\begin{abstract}
Every public company is required to submit financial statements audited by public accountant every year. This study examines the effect of the increase in assets, increase in profitability and increase in liquidity on leverage of public companies in the trade, services and investment sector, which are listed on the stock exchanges of Indonesia. This study used multivariate equation model. The study found that the increase in assets providing a positive influence but not significant. The increase in profitability provides positive influence and significant, while the increase in liquidity provides negative effect significantly.
\end{abstract}

Keywords: the increase in asset, increase in profitability, increase in liquidity, leverage

\begin{abstract}
Abstrak: Setiap perusahaan publik wajib menyampaikan laporan keuangan yang telah diaudit oleh akuntan publik setiap tahun. Penelitian ini menguji pengaruh kenaikan aset, peningkatan profitabilitas dan meningkatkan likuiditas pada leverage perusahaan publik dalam perdagangan, jasa dan investasi sektor, yang terdaftar di bursa efek Indonesia. Penelitian ini menggunakan model persamaan multivariat. Studi ini menemukan bahwa peningkatan aset memberikan pengaruh positif tetapi tidak signifikan. Peningkatan profitabilitas memberikan pengaruh positif dan signifikan, sedangkan peningkatan likuiditas memberikan efek negatif secara signifikan.
\end{abstract}

Kata kunci: peningkatan aset, peningkatan profitabilitas, peningkatan likuiditas, Leverage

\section{PENDAHULUAN}

Pendanaan bagi suatu perusahaan merupakan suatu hal yang penting. Perusahaan yang berkembang selalu memerlukan pendanaan untuk pembelian aset-aset baru. Peningkatan dalam aset biasanya mendorong manajemen untuk menambah pendanaan baru. Peningkatan dalam profitabilitas dapat menambah keyakinan bagi perusahaan untuk bertumbuh, yang mana pertumbuhan perusahaan juga dapat mendorong perusahaan untuk melakukan pendanaan tambahan. Faktor peningkatan dalam likuiditas juga dapat memberi tambahan keyakinan bagi perusahaan dalam hal kemampuan perusahaan untuk melunasi kewajibannya. Hal inipun dapat menjadi dasar pertimbangan bagi perusahaan yang sedang merencanakan pendanaannya. Terdapat dua bentuk sumber pendanaan bagi perusahaan, yaitu bentuk utang dan bentuk ekuitas. Apapun bentuk pendanaan yang dipilih perusahaan, akan dapat mempengaruhi struktur leveragenya. Tentu sesungguhnya ada banyak faktor yang dapat mempengaruhi tingkat leverage perusahaan, tetapi studi ini hanya akan menguji pengaruh peningkatan dalam aset, peningkatan dalam profitabilitas dan peningkatan dalam likuiditas. 
Tujuan dalam penyusunan penelitian ini adalah: (1) Untuk menguji pengaruh peningkatan aset terhadap leverage perusahaan sektor perdagangan, jasa dan investasi yang terdaftar di Bursa Efek Indonesia.; (2) Untuk menguji pengaruh peningkatan profitabilitas terhadap leverage perusahaan sektor perdagangan, jasa dan investasi yang terdaftar di Bursa Efek Indonesia.; (3) Untuk menguji pengaruh peningkatan likuiditas terhadap leverage perusahaan sektor perdagangan, jasa dan investasi yang terdaftar di Bursa Efek Indonesia.; (4) Untuk menguji pengaruh peningkatan aset, peningkatan profitabilitas dan peningkatan likuiditas secara bersama-sama terhadap leverage perusahaan sektor perdagangan, jasa dan investasi yang terdaftar di Bursa Efek Indonesia.

\section{KAJIAN TEORI}

Manajemen keuangan adalah suatu aktivitas perencanaan, pengaplikasian dan pengendalian dari pemanfaatan dana, pencarian dana dan pembagian laba. Secara bersama-sama, ketiga keputusan keuangan merupakan penentu tinggi rendahnya nilai perusahaan. Maka diperlukan suatu perpaduan yang optimal dari ketiga keputusan yang saling terkait. Wibisono (1997) menjelaskan bahwa keputusan investasi pasti perlu dana, dilain pihak keputusan pendanaan saling mempengaruhi dengan keputusan dividen, nampak dalam penggunaan sumber dana internal yang berasal dari keuntungan yang tidak dibagi. Apabila memahami bagai mana dan mengapa akuntansi itu ada, bagai mana pula laporan keuangan dimanfaatkan, maka akan dapat membayangkan dengan lebih baik apa yang sedang terjadi, dan mengapa Informasi akuntansi mempunyai makna yang amat penting. Laporan keuangan bertujuan untuk memberikan informasi tentang posisi keuangan, kinerja dan arus kas perusahaan yang bermanfaat bagi sebagian besar kalangan pengguna laporan dalam rangka membuat keputusan-keputusan ekonomi serta menunjukkan pertanggungjawaban manajemen atas penggunaan sumber-sumber daya yang dipercayakan kepada mereka.” (Ikatan Akuntan Indonesia, 2007). Laporan keuangan merupakan bagian dari proses pelaporan laporan keuangan. Laporan keuangan yang lengkap biasanya meliputi neraca, laporan laba rugi, laporan posisi keuangan (yang dapat disajikan dalam berbagai cara seperti, sebagai laporan arus kas, atau laporan arus dana), catatan dan laporan lain serta materi penjelasan yang merupakan bagian integral dari laporan keuangan (Ikatan Akutansi Indonesia , 2007). Ada empat karakteristik kualitatif pokok dalam sebuah laporan keuangan yaitu: (a) dapat dipahami,(b) relevan,(c) keandalan dan (d) dapat diperbandingkan (Ikatan Akuntan Indonesia, 2007). Terdapat lima alat analisis laporan keuangan yaitu: (a) comparative financial statement analysis, (b) common-size financial statement analysis, (c) ratio analysis, (d) cashflow analysis dan(e) valuation. comparative financial statement analysis merupakan analisis laporan keuangan dengan memeriksa laporan neraca, laporan laba rugi, laporan arus kas dari satu periode ke periode lain (Wild et al, 2006).

Hanafi (2005) mengungkapkan bahwa analisis laporan keuangan perusahaan dilaksanakan dengan alasan untuk mengetahui tingkat profitabilitas, resiko atau tingkat kesehatan suatu perusahaan. Jadi suatu laporan keuangan merupakan keterangan yang memuat Informasi tentang posisi keuangan, hasil usaha, perubahan ekuitas dan arus kas perusahaan. (Darsono dan Ashari, 2005). Oleh sebab itulah maka suatu laporan keuangan merupakan suatu laporan pertanggung jawaban dari pihak manajemen perusahaan atas pengelolaan perusahaan yang telah dipercayakan kepada mereka kepada pihak-pihak yang 
memiliki kepentingan baik yang berasal dari luar perusahaan; pemilik perusahaan, pemerintah, kreditor atau pihak lainnya. Pengertian dari Laporan keuangan adalah suatu gambaran tentang posisi keuangan dari sebuah perusahaan pada satu masa periode tertentu. Analisa laporan keuangan merupakan analisa atas kondisi keuangan dari suatu perusahaan yang meliputi neraca, laporan laba rugi, laporan perubahan ekuitas, laporan arus kas dan catatan atas laporan keuangan. Analisis laporan keuangan merupakan kebutuhan bagi pihak - pihak yang berkepentingan di dalam maupun di luar perusahaan, antara lain dari pihak pemilik perusahaan untuk mengetahui kondisi keuangan, dari pihak investor untuk memahami kondisi keuangan perusahaan sebagai dasar pertimbangan dalam melakukan investasi ke dalam perusahaan tersebut, dari pihak kreditor untuk memahami kondisi keuangan perusahaan sebelum memberikan pinjaman sebagai pertimbangan atas resiko terutama resiko kredit macet. Untuk pihak investor, informasi mengenai kinerja perusahaan dapat digunakan untuk melihat apakah mereka akan mempertahankan investasi mereka di perusahaan tersebut atau mencari alternatif lain. Jika kinerja perusahaan baik maka nilai usaha akan tinggi. Pada posisi nilai usaha yang tinggi membuat para investor melirik perusahaan tersebut untuk menanamkan modalnya sehingga akan terjadi kenaikan harga saham. Jadi harga saham merupakan fungsi dari nilai perusahaan. Suatu laporan keuangan dipakai sebagai dasar bagi pihak manajemen perusahaan maupun investor untuk melakukan penilaian terhadap kinerja perusahaan secara keseluruhan yang telah dicapai oleh perusahaan di masa lalu sehingga dapat dipakai untuk kepentingan pengambilan keputusan. Menurut Standar Akuntansi Keuangan tahun 2007, tujuan laporan keuangan adalah menyediakan informasi yang menyangkut posisi keuangan, kinerja, serta perubahan posisi keuangan suatu perusahaan yang bermanfaat bagi sejumlah besar pengguna dalam mengambil keputusan ekonomi.

Munawir (2001) menjelaskan bahwa perusahaan dikatakan memiliki kondisi keuangan yang baik apabila mampu memenuhi: (a) kewajiban-kewajibanya tepat waktu; (b) memelihara modal kerja yang cukup untuk biaya operasional; (c) Membayar bunga dan dividen yang dibutuhkan dan (d) Memelihara tingkat kredit yang menguntungkan. Suatu laporan keuangan wajib disusun dalam bentuk yang paling cocok bagi perusahaan agar dapat memberikan manfaat yang optimal bagi pemakai laporan keuangan serta wajib dinyatakan dalam satuan mata uang agar menunjukkan bahwa transaksi dan peristiwa yang terjadi adalah suatu informasi yang berkaitan dengan data ekonomi perusahaan dan bersifat kuantitatif. Maka jelaslah bahwa laporan keuangan bukanlah sekedar menyajikan data yang telah diproses saja, karena tujuan utama dari laporan keuangan adalah merupakan sarana komunikasi dalam menyampaikan keterangan yang bermanfaat bagi semua pengguna laporan keuangan supaya mereka dapat memahami tentang kondisi kesehatan perusahaan yang sebenar-benarnya, agar supaya mereka bisa membuat keputusan yang sesuai sasaran. Hanafi (2005) menegaskan bahwa suatu laporan keuangan dapat memberi Informasi tentang perusahaan dan digabungkan dengan Informasi yang lain seperti industri, kondisi ekonomi, serta dapat memberikan pula gambaran yang lebih baik mengenai prospek dan resiko perusahaan. Salah satu laporan keuangan yang sering dipakai adalah Neraca, yang mana menurut Rahardjo (2003) ditegaskan bahwa Neraca adalah suatu laporan posisi keuangan perusahaan pada tanggal tertentu.

Keown et. Al, (2005) menjelaskan bahwa suatu analisis rasio keuangan dapat menggambarkan banyak hal dalam keuangan perusahaan, namun terdapat keterbatasan sebagai berikut : Sulit untuk mengidentifikasi kategori industri dari perusahaan pada saat perusahaan memiliki lebih dari satu jalur bisnis; Rata-rata industry yang dipublikasikan 
merupakan angka tafsiran dan panduan umum bagi para pemakai serta bukan merupakan rata-rata rasio yang ditentukan secara ilmiah atas semua kejadian pada perusahaan yang mewakili dalam industri; Perbedaan praktik akuntansi di antara perusahaan dan dapat mengarah pada perbedaan perhitungan rasio; Rata-rata industri mungkin tidak menunjukkan target rasio dan perilaku yang diinginkan; Banyak perusahaan berpengalaman secara musiman dalam kegiatan operasinya. Rasio likuiditas adalah rasio yang mengukur kemampuan perusahaan dalam memenuhi liabilitas finansial yang telah jatuh tempo dalam jangka pendek. Rasio ini menunjukkan hubungan antara kas dan aset lancar lainnya dari sebuah perusahaan dengan liabilitas jangka pendeknya (Keown et al, 2005). Ada beberapa komponen yang biasa terdapat di dalam laporan keuangan yaitu : (a) laporan laba rugi, (b) laporan modal pemilik, (c) neraca, (d) laporan arus kas dan (e) catatan atas laporan keuangan. Laporan laba rugi yaitu ikhtisar dari penghasilan dan beban suatu perusahaan dalam periode tertentu misalnya sebulan atau setahun (Warren et al, 2005). Menurut Hanafi (2005), suatu perusahaan adalah salah satu bentuk organisasi pada umumnya memiliki tujuan tertentu yang ingin dicapai dalam usaha untuk memenuhi kepentingan para anggotanya.Keberhasilan dalam mencapai tujuan perusahaan merupakan prestasi manajemen. Kinerja perusahaan sendiri dapat diartikan sebagai suatu usaha formal yang dilaksanakan perusahaan untuk mengevaluasi efisien dan efektivitas dari aktivitas perusahaan yang telah dilaksanakan pada periode waktu tertentu.

Pendanaan merupakan suatu upaya perusahaan untuk meraih dana bagi pengembangan perusahaan. Bentuk pendanaan perusahaan di Amerika Serikat antara tahun 1979 sampai dengan tahun 1999 ternyata bahwa hampir 80\% dipakai untuk belanja modal dan sisanya dipakai untuk modal kerja. Sumber pendanaan yang dipakai bersumber dari pendanaan internal hampir 70\% dan pendanaan eksternal 30\% yang mana komposisi utang melebihi saham.(Ross, 2005). Pandey (2001) menambahkan bahwa kondisi ekonomi memberi pengaruh yang penting dalam kebijakan utang perusahaan. Suatu modal merupakan hak yang dimiliki oleh pemilik perusahaan yang ditujukan dalam pos modal, surplus dan laba ditahan, atau kelebihan aktiva yang dimiliki oleh perusahaan terhadap seluruh hutang-hutangnya. Asal usul modal dapat berupa hutang lancar, hutang jangka panjang dan modal sendiri. Modal menggambarkan hak pemilik atas perusahaan yang timbul sebagai akibat penanaman investasi yang dilakukan oleh pemilik (Munawir, 2001). Dana internal lebih disukai dari dana eksternal karena dana internal memungkinkan perusahaan untuk tidak membuka diri dari sorotan pemodal luar. Jika diperlukan, dana eksternal dalam bentuk hutang lebih disukai karena pertimbangan biaya emisi (Prabansari dan Kusuma, 2005). Ang (1997) menyatakan bahwa aset adalah aktiva yang digunakan untuk aktivitas operasional perusahaan. Semakin besar aset diharapkan semakin besar hasil operasional yang dihasilkan oleh perusahaan. Suatu peningkatan aset yang diikuti peningkatan hasil operasi akan semakin menambah kepercayaan pihak luar terhadap perusahaan. Dengan peningkatan kepercayaan pihak luar (kreditor) terhadap perusahaan, maka proporsi hutang semakin lebih besar daripada modal sendiri. Hal ini didasarkan pada keyakinan kreditor atas dana yang ditanamkan kedalam perusahaan dijamin oleh besarnya aset yang dimiliki perusahaan (Ang,1997).

Suatu rasio profitabilitas adalah rasio untuk menilai kemampuan perusahaan dalam mencari keuntungan. Rasio ini juga memberikan ukuran tingkat efektifitas manajemen suatu perusahaan. Hal ini ditunjukkan oleh laba yang dihasilkan dari penjualan dan pendapatan investasi. Jadi rasio profitabilitas menunjukan efisiensi perusahaan. Pengertian profitabilitas merupakan kemampuan perusahaan untuk menghasilkan profit 
selama satu tahun dengan menggunakan asset perusahaan, baik lancar maupun tetap dalam aktivitas produksi. Tanpa profit, perusahaan tidak dapat menarik sumber modal eksternal untuk menginvestasikan dananya pada perusahaan (Gitman, 2009). Return on asset diukur dari laba bersih setelah pajak terhadap total asetnya yang mencerminkan kemampuan perusahaan dalam penggunaan investasi yang digunakan untuk operasi perusahaan dalam rangka menghasilkan profitabilitas perusahaan ( Ang, 1997). Shapiro (1992) menjelaskan bahwa profitabilitas dapat digunakan untuk mengukur kinerja suatu perusahaan yang dalam hal ini pasti berorientasi pada profit motif atau keuntungan yang diraih oleh perusahaan tersebut. Suatu Profitability analysis yang diimplementasikan dengan profitability ratio, disebut juga operating ratio. Pada operating ratio terdapat dua tipe rasio yaitu margin on sale dan return on asset. Profit margin digunakan untuk mengukur kemampuan perusahaan untuk mengendalikan pengeluaran yang berhubungan dengan penjualan, yaitu meliputi gross profit margin, operating profit margin, dan net profit margin. Hubungan antara return on asset dan share holder equity ada dua ukuran, yakni Return On Asset yang biasanya juga disebut Return On Investment dan Return On Equity (Shapiro, 1992). Sartono (2001) menyatakan bahwa profitabilitas merupakan faktor penting dalam menentukan struktur modal. Perusahaan dengan tingkat pengembalian yang tinggi atas investasi akan menggunakan hutang yang relatif rendah. Tingkat pengembalian yang tinggi memungkinkan untuk membiayai sebagian besar kebutuhan pendanaan dengan dana yang dihasilkan secara internal. Perusahaan yang mempunyai profit tinggi akan menggunakan hutang dalam jumlah rendah, dan sebaliknya (Brigham dan Houston, 2001).

Suatu Return on Equity ( $R O E$ ) adalah perbandingan antara laba bersih dengan ekuitas dan merupakan salah satu dari dua faktor dasar dalam menentukan pertumbuhan tingkat pendapatan perusahaan (Bodie et al, 2011). Terdapat dua sisi dalam memakai $R O E$, terkadang diasumsikan bahwa $R O E$ yang akan datang merupakan perkiraan dari $R O E$ yang lalu. Tetapi $R O E$ yang tinggi pada masa yang lalu tidak menjamin $R O E$ yang akan datang masih tetap tinggi. Penurunan $R O E$ merupakan bukti bahwa investasi baru pada perusahaan tersebut menghasilkan $R O E$ yang lebih rendah dari investasi lama. Hal yang paling penting yang bisa disimpulkan dari para analis adalah tidak perlu menerima nilai historis sebagai indikator nilai yang akan datang ( Bodie et al, 2011). Rasio Return on Equity merupakan rasio untuk mengetahui keberhasilan perusahaan dalam menghasilkan laba bagi para pemegang saham. Return on equity dianggap sebagai representasi dari kekayaan pemegang saham atau nilai perusahaan (Mardiyanto, 2009). Rasio Return on Equity adalah rasio penting bagi pemilik perusahaan, sebab rasio ini menunjukkan tingkat pengembalian yang dihasilkan oleh perusahaan dari modal yang disediakan oleh pemilik perusahaan. Berarti Return on Equity menunjukan keuntungan yang akan dinikmati oleh pemilik saham. Adanya peningkatan Return on Equity menunjukan prospek perusahaan yang semakin baik karena berarti adanya potensi peningkatan keuntungan yang diperoleh perusahaan (Mardiyanto, 2009).

Suatu struktur modal adalah hal penting dalam pengambilan keputusan pembelanjaan perusahaan. Struktur modal memakai rasio struktur modal yang disebut leverage ratio. Leverage ratio adalah perbandingan yang bertujuan untuk mengukur seberapa besar suatu perusahaan dibiayai oleh hutang (Munawir, 2001). Suatu financial leverage memiliki tiga implikasi penting, yaitu: (1) Memperoleh dana melalui utang membuat pemegang saham dapat mempertahankan pengendalian atas perusahaan dengan investasi yang terbatas; (2) Kreditor melihat ekuitas atau dana yang disetor oleh pemilik untuk memberikan margin of 
safety, sehingga jika pemegang saham hanya memberikan sebagian kecil dari total pembiayaan, maka risiko perusahaan sebagian besar terdapat pada kreditor; (3) Jika perusahaan memperoleh pengembalian yang lebih besar dari asetnya dibanding pembayaran bunga atas utangnya, maka pengembalian atas pemilik modal akan lebih besar (Brigham dan Houston, 2008). Menurut Riyanto (1995), ROE adalah rasio yang mengukur kemampuan modal sendiri atau kekayaan dalam menghasilkan keuntungan bersih bagi pemegang saham biasa maupun saham preferen. ROE yang positif menunjukkan bahwa total ekuitas yang dipergunakan untuk operasi perusahaan mampu memberikan laba bagi perusahaan dan apabila ROE negatif menunjukkan bahwa dari total ekuitas yang digunakan, perusahaan mengalami kerugian. Return On Equity merupakan rasio rentabilitas yang menunjukan berapa persen perolehan laba bersih bila di ukur dari modal pemilik. Return on Equity (ROE) merupakan rasio yang merefleksikan seberapa banyak perusahaan telah memperoleh hasil atas dana yang telah dinvestasikan oleh pemegang saham (Harahap, 2004).

Sundjaja dan Barlian (2003) menjelaskan bahwa Debt to Equity ratio (DER) merupakan perbandingan antara hutang dengan total equity perusahaan, jadi DER mencerminkan besarnya proporsi antara total debt (total hutang) dan total shareholder's equity (total modal sendiri). Total debt merupakan total liabilities (baik utang jangka pendek maupun jangka panjang); sedangkan total shareholders'equity merupakan total modal sendiri (total modal saham yang disetor dan laba yang ditahan yang dimiliki perusahaan). Debt to Equity Ratio yang semakin rendah maka semakin baik kemampuan perusahaan untuk dapat bertahan dalam kondisi yang buruk. Debt to Equity Ratio yang rendah menunjukan bahwa perusahaan masih mampu memenuhi kewajibannya kepada kreditur, hak kreditur terhadap aktiva perusahaan lebih besar dibandingkan dengan hak pemegang saham. (Warren, Reeve, dan Fess, 2005). Apabila perusahaan mengalami kebangkrutan maka pembayaran kewajiban kepada kreditur lebih didahulukan daripada membagikan hak pemegang saham. Maka pemegang saham lebih menyukai Debt to Equity Ratio yang lebih rendah, karena semakin rendah rasionya maka semakin kecil tingkat kerugian yang akan dialami oleh investor jika terjadi likuidasi atau kebangkrutan (Warren, Reeve, dan Fess, 2005).

Leverage atau struktur modal suatu perusahaan merupakan rasio jumlah utang jangka pendek, utang jangka panjang, dan saham biasa yang dipergunakan. (Sartono, 2001). Damodaran (2001) menjelaskan bahwa leverage atau struktur modal merupakan campuran antara utang dan ekuitas, yang mana ditambahkan pula bahwa didalam melakukan analisis leverage dipakai analisis debt ratio (DR). Struktur modal adalah campuran dari berbagai utang dan modal ekuitas yang dikelola oleh perusahaan. Komposisi efek sebuah korporasi digunakan untuk membiayai kegiatan investasinya; proporsi relatif dari utang jangka pendek, hutang jangka panjang, dan ekuitas pemilik (Ross, 2005). Hal-hal yang dapat berpengaruh terhadap leverage adalah profitability dan besarnya suatu perusahaan. (Voulgari, et al. 2002). Selain itu, Hall et al,(2004) menjelaskan pula bahwa hal-hal yang dapat juga berpengaruh terhadap leverage adalah country-specific variables. Terakhir, Cassar dan Holmes (2003) menambahkan bahwa hal-hal yang bisa berpengaruh terhadap leverage adalah struktur aktiva, profitability, dan tingkat pertumbuhan (Gambar 1).

Berdasarkan teori-teori dan konsep yang ada maka dapat dibangun hipotesis sebagai berikut:

H1: peningkatan aset berpengaruh terhadap leverage perusahaan sektor perdagangan, jasa dan investasi yang terdaftar di Bursa Efek Indonesia. 
H2: peningkatan profitabilitas berpengaruh terhadap leverage perusahaan sektor perdagangan, jasa dan investasi yang terdaftar di Bursa Efek Indonesia.

H3: Peningkatan likuiditas berpengaruh terhadap leverage perusahaan sektor perdagangan, jasa dan investasi yang terdaftar di Bursa Efek Indonesia.

H4: peningkatan aset, peningkatan profitabilitas dan peningkatan likuiditas secara bersama-sama berpengaruh terhadap leverage perusahaan sektor perdagangan, jasa dan investasi yang terdaftar di Bursa Efek Indonesia.

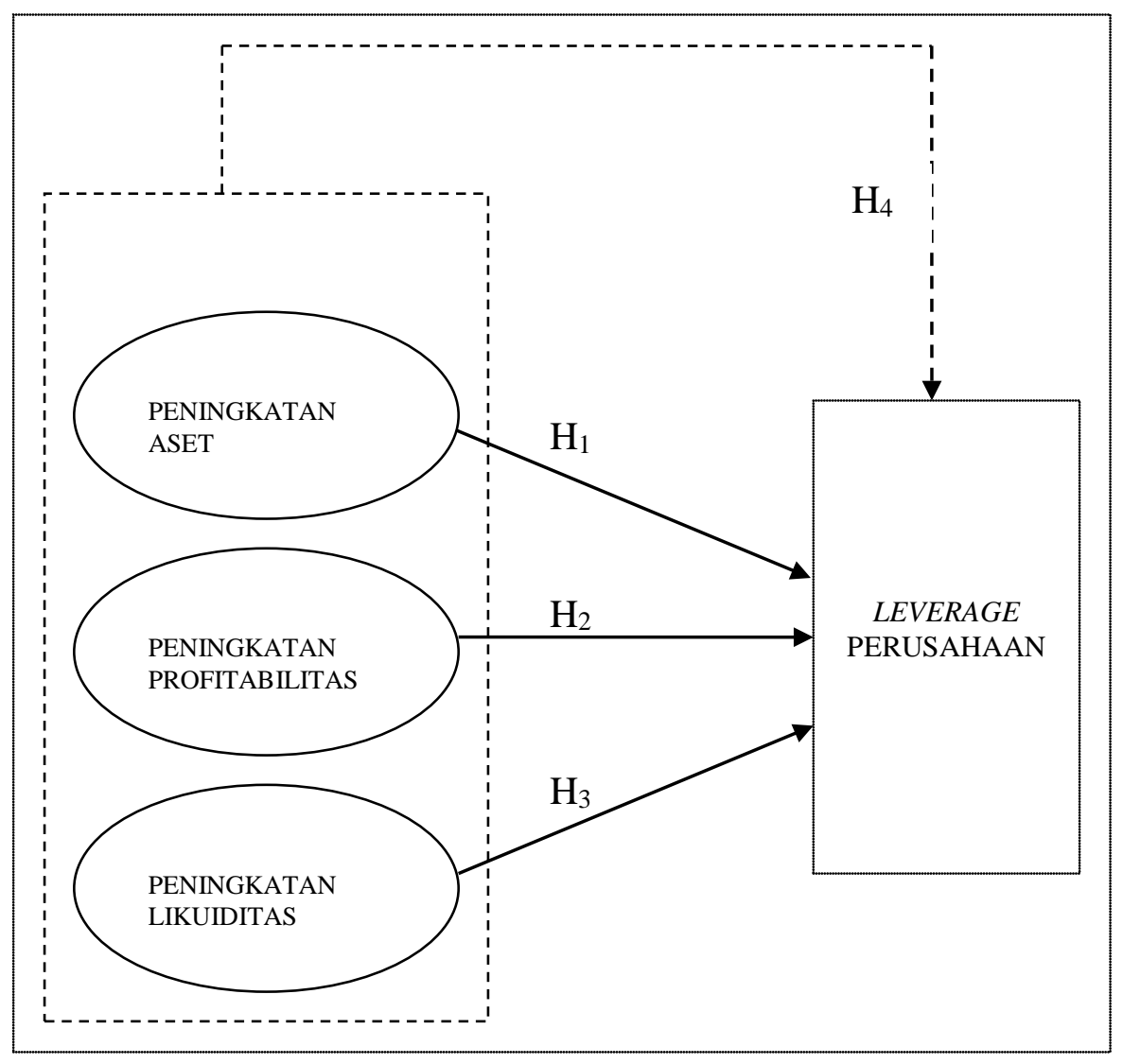

Gambar 1. Kerangka Konseptual

\section{METODE}

Obyek penelitian dalam studi ini adalah Perusahaan perusahaan go public dalam sektor perdagangan, jasa dan investasi yang terdaftar di Bursa Efek Indonesia. Periode data yang dipakai dalam penelitian ini adalah dari tahun 2006 sampai dengan 2009. Semua variabel yang dianalisis dalam penelitian ini, dapat dikelompokkan menjadi dua macam. Pertama adalah variabel tak bebas (dependent variable) yaitu debt ratio (DR) sebagai proxy dari leverage perusahaan. Kedua, variabel bebas (independent variable) yaitu peningkatan asset (PASET), peningkatan return on equity (PROE) sebagai proxy dari peningkatan profitabilitas dan peningkatan quick ratio (PQR) sebagai proxy dari peningkatan likuiditas.

(1) DR merupakan perbandingan total debt terhadap total aktiva perusahaan

(2) PASET dihitung dengan rumus sebagai berikut: 


$$
\text { PASET }=\frac{\text { Asset }_{i t}-\text { Asset }_{i t-1}}{\text { Asset }_{i t-1}}
$$

Dimana: Asset adalah Total aset perusahaan ; $t$ adalah tahun ke-t.

(3) PROE dihitung dengan rumus sebagai berikut :

$$
\text { PROE }=\frac{R O E_{i t}-R O E_{i t-1}}{R O E_{i t-1}}
$$

Dimana: ROE adalah return on equity perusahaan .

(4) QR dihitung dengan rumus sebagai berikut :

$$
\mathbf{P Q R}=\frac{Q R_{i t}-Q R_{i t-1}}{Q R_{i t-1}}
$$

Dimana: QR adalah quick ratio perusahaan .

Untuk dapat melaksanakan penelitian ini pengolahan data dilakukan dengan software pengolah data SPSS (Statistical Package for the Social Science). Penelitian ini menggunakan model multifaktor dalam bentuk persamaan regresi multivariat yang terdiri dari sebuah variabel dependen dan beberapa variabel independen. Model persamaannya adalah sebagai berikut:

$$
\text { DR }_{\text {it }}=\beta_{0}+\beta_{1} \text { PASET }_{\text {it }}+\beta_{2} \text { PROE }_{\text {it }}+\beta_{3} \text { PQR }_{\text {it }}+\varepsilon
$$

Keterangan:

$\mathrm{DR}_{\mathrm{it}}=\mathrm{DR}$ saham i pada periode $\mathrm{t}$; PASET it $=$ Peningkatan Asset saham $\mathrm{i}$ pada periode $\mathrm{t} ; \mathrm{PROE}_{\mathrm{it}}=$ Peningkatan ROE saham i pada periode $\mathrm{t} ; \mathrm{PQR}_{\mathrm{it}}=$ Peningkatan $\mathrm{QR}$ saham i pada periode t; $\varepsilon=$ error term; $\beta_{1}, \beta_{2}, \beta_{3}=$ koefisien dari masing masing variabel bebas

Studi ini menggunakan metode estimasi Ordinary Least Square (metode kuadrat terkecil) serta memakai data panel. Menurut Pindyck \& Rubinfeld (1998) asumsi dasar yang harus dipenuhi meliputi sebagai berikut: (a) Error dari observasi-observasi yang berbeda adalah independent dan karenanya tidak berkorelasi (No autocorrelation).; (b) Model persamaan merupakan model linear secara parameter.; (c) Error memiliki nilai harapan 0 (nol) untuk semua observasi.; (d) Variabel independen tidak ada hubungan linear yang persis antara dua atau lebih di antara mereka (No multicollinearity).; (e) Error memiliki varians yang konstan untuk semua observasi (No heteroscedasticity).; (f) Error berdistribusi normal.

Pengujian Normalitas. Dalam hal ini pengujian normalitas dilakukan untuk menguji apakah data memiliki distribusi normal atau mendekati normal dengan melihat normal probability plot dimana jika data menyebar di sekitar garis diagonal dan mengikuti arah garis diagonal maka model regresi memenuhi asumsi normalitas (Ghozali, 2005). Data yang baik adalah data yang mempunyai pola distribusi normal, yang terlihat dari sebaran data yang bergerombol di sekitar garis uji dan tidak ada data yang terletak jauh dari sebaran data (Santoso, 2004), dalam SPSS hal ini terlihat sebagai gambar PP Plots. Cara alternatif lain untuk menguji normalitas dapat menggunakan uji One-Sample KolmogorovSmirnov Test. Uji normalitas dengan uji Kolmogorov-Smirnov dapat dirumuskan sebagai berikut:

Hipotesis : $\quad \mathrm{H}_{0}=$ sampel berdistribusi normal

$$
\mathrm{H}_{1}=\text { sampel tidak berdistribusi normal }
$$


Jika Asymp Sig (2-tailed) $>\propto(0,05)$, maka $\mathrm{H}_{0}$ diterima. Jika Asymp Sig (2-tailed) $<\propto(0,05)$, maka $\mathrm{H}_{0}$ ditolak.

Pengujian Multikolinearitas. Dalam penelitian ini, pengujian multikolinearitas terutama ditujukan untuk menguji apakah pada suatu model regresi ditemukan adanya korelasi antar variabel independen. Multikolinearitas berhubungan dengan situasi dimana ada hubungan linear baik yang pasti atau mendekati pasti diantara variabel independen (Gujarati, 2003). Jika terjadi korelasi maka dinamakan terdapat problem multikolinearitas. Model yang baik seharusnya tidak terjadi korelasi diantara variabel indenpenden. Menurut Ghozali (2005) deteksi adanya multikolinearitas dibuktikan dengan menggunakan besaran VIF (Variance Inflation Factor) kurang dari 10 dan Tolerance mempunyai angka lebih besar dari 0,1.

Pengujian Otokorelasi. Tujuan pengujian otokorelasi untuk menguji apakah dalam sebuah model regresi linear ada korelasi antara kesalahan penggangu pada periode $t$ dengan kesalahan pada periode t-1 (sebelumnya). Jika terjadi korelasi maka dinamakan ada problem autokorelasi. Salah satu cara untuk mengurangi otokorelasi adalah dengan melakukan tranformasi logaritma (Nachrowi dan Usman, 2002). Model regresi yang baik adalah regresi yang bebas dari autokorelasi. Menurut Santoso (2001), deteksi adanya autokorelasi menggunakan besaran Durbin Watson (DW).

Pengujian Heteroskedastisitas. Tujuan pengujian heteroskedastisitas untuk menguji apakah dalam suatu model regresi, terjadi ketidaksamaan varians dari residual dari satu pengamatan ke pengamatan lainnya. Jika varians dari residual dari satu pengamatan ke pengamatan lainnya tetap maka disebut Homoskedastisitas dan jika varians berbeda disebut Heteroskedastisitas. Menurut Santoso (2001) deteksi adanya heterokedastisitas dilakukan dengan melihat Scatter Plot jika:

(1) Tidak ada pola yang jelas serta titik-titik menyebar diatas angka 0 dan dibawah angka 0 pada sumbu Y maka tidak terjadi heteroskedatisitas.

(2) Adanya pola tertentu seperti titik-titik yang membentuk suatu pola yang teratur (bergelombang, melebar, kemudian menyempit) maka telah terjadi heteroskedastisitas.

Pengujian Goodness of Fit .Keberadaan koefisien determinasi digunakan untuk mengukur seberapa besar variasi variabel dependen dapat dijelaskan oleh variasi variabel independen sedangkan sisa variasi yang tidak dapat dijelaskan merupakan bagian yang dijelaskan oleh variabel lain yang tidak terdapat didalam model regresi yang diuji.(Ghozali, 2005). Menurut Lind (2002) yang terdapat dalam Suharyadi dan Purwanto (2004), apabila nilai koefisien determinasi lebih besar 0,5 menunjukkan variable bebas dapat menjelaskan variabel tidak bebas dengan baik atau kuat, sama dengan 0,5 dikatakan sedang. Pemanfaatan koefisien determinasi disesuaikan (adjusted $R$ square) pada regresi berganda lebih baik dalam melihat seberapa baik model, dibandingkan koefisien determinasi.

Penggunaan uji $\mathrm{F}$ untuk menunjukkan pengaruh variabel independen terhadap variabel dependen secara bersama sama. Jika angka signifikan $<0,5$ maka model regresi ini dapat dipakai untuk memprediksi variabel dependen karena angka tersebut menunjukkan semua variabel independen secara keseluruhan merupakan penjelas yang signifikan terhadap variabel dependen.(Ghozali, 2005). Penggunaan uji t untuk menguji pengaruh dari masing-masing variabel bebas terhadap variabel terikat. Pengujian t bisa 
dilakukan dengan 2 cara yaitu dengan melihat tingkat signifikansi atau dengan membandingkan t hitung dengan t tabel.

Pengujian Hipotesis. Beberapa hipotesis yang akan diuji adalah:

Pengaruh PASET terhadap DR

$\mathrm{H}_{1} 0: \beta_{1}=0$ ( PASET tidak mempengaruhi DR)

$\mathrm{H}_{1} \mathrm{a}: \beta_{1} \neq 0$ ( PASET mempengaruhi DR)

Pengaruh PROE terhadap DR

$\mathrm{H}_{2} 0: \beta_{2}=0$ (PROE tidak mempengaruhi DR)

$\mathrm{H}_{2} \mathrm{a}: \beta_{2} \neq 0$ (PROE mempengaruhi DR)

Pengaruh PQR terhadap DR

$\mathrm{H}_{3} 0: \beta_{3}=0$ (PQR tidak mempengaruhi DR)

$\mathrm{H}_{3} \mathrm{a}: \beta_{3} \neq 0$ (PQR mempengaruhi DR)

Pengaruh PASET, PROE dan PQR secara bersama-sama terhadap DR

$\mathrm{H}_{4} 0: \beta_{1}=\beta_{2}=\beta_{3}=0$

(PASET, PROE dan PQR secara bersama-sama tidak mempengaruhi DR)

$\mathrm{H}_{4} \mathrm{a}: \beta_{1} \neq \beta_{2} \neq \beta_{3} \neq 0$

(PASET, PROE dan PQR secara bersama-sama mempengaruhi DR)

\section{HASIL DAN PEMBAHASAN}

Atas dasar ketersediaan data yang ada, didapat jumlah data yang dipakai untuk obyek penelitian berjumlah lima puluh perusahaan yang tercatat di BEI selama empat tahun berjumlah dua ratus pengamatan.

Tabel 1. Daftar Perusahaan Sampel

\begin{tabular}{llll}
\hline Kode & Nama Perusahaan & Kode & Nama Perusahaan \\
\hline AKRA & PT AKR Corporindo Tbk & TKGA & PT Toko Gunung agung Tbk \\
CLPI & PT Colorpak Indonesia Tbk & ANTA & PT Anta Ekspres Tour \& Tr Tbk \\
EPMT & PT Enseval Putra Mega Tbk & BAYU & PT Bayu Buana Tbk \\
GEMA & PT Gema Grahasarana Tbk & FAST & PT Fast Food Indonesia Tbk \\
HEXA & PT Hexindo Adiperkasa Tbk & GMCW & PT Grahamas Citrawisata Tbk \\
INTA & PT Intraco Penta Tbk & JSPT & PT Jakarta Setiabudi Int’l Tbk \\
INTD & PT Inter Delta Tbk & MAMI & PT Mas Murni Indonesia Tbk \\
KONI & PT Perdana Bangun Persada Tbk & PANR & PT Panorama Sentrawisata Tbk \\
LTLS & PT Lautan Luas Tbk & PJAA & PT Pembangunan Jaya Ancol Tbk \\
MDRN & PT Modern International Tbk & PLIN & PT Plaza Indonesia Realty Tbk \\
TGKA & PT Tigaraksa Satria Tbk & PNSE & PT Pudjiadi \& Sons Estat Tbk \\
TIRA & PT tira Austenite Tbk & SHID & PT Hotel Sahid jaya Tbk \\
TMPI & PT AGIS Tbk & FORU & PT Fortune Indonesia Tbk \\
TURI & PT Tunas Ridean Tbk & IDKM & PT Indosiar Karya Media Tbk \\
UNTR & PT United Traktor Tbk & SCMA & PT Surya Citra Media Tbk \\
WICO & PT Wicaksana Overseas Tbk & TMPO & PT Tempo Inti Media Tbk \\
ALFA & PT Alfa Retailindo Tbk & ASGR & PT Astra Graphia Tbk \\
CSAP & PT Catur Sentosa Adiprana Tbk & CENT & PT Centrine Online Tbk \\
HERO & PT Hero Supermarkaet Tbk & DNET & PT Dyviacom Intrabumi Tbk \\
MAPI & PT Mitra Adiperkasa Tbk & INDX & PT Indoexchange Tbk \\
MPPA & PT Matahari Putra Prima Tbk & LMAS & PT Limas Centric Indonesia Tbk
\end{tabular}


Lanjutan Tabel 1

\begin{tabular}{llll}
\hline Kode & Nama Perusahaan & Kode & Nama Perusahaan \\
\hline MTSM & PT Metro Supermarket Rlt Tbk & MTDL & PT Metrodata Elektronik Tbk \\
RALS & PT Ramayana Lestari Sent Tbk & BHIT & PT Bhakti Investama Tbk \\
RIMO & PT Rimo Catur Lestari Tbk & BNBR & PT Bakrie \& Brothers Tbk \\
SONA & PT Sona Topas turism Tbk & MLPL & PT Multipolar Tbk \\
\hline
\end{tabular}

Dari analisis hasil penelitian akan dimulai dengan membahas hasil pengujian atas validitas data yaitu pengujian asumsi klasik yang meliputi uji normalitas data, uji multikolineritas, uji autokorelasi dan uji heteroskedastisitas. Kemudian akan dilanjutkan dengan analisis atas pengujian hipotesis penelitian dengan metode regresi liner berganda. Lalu dilanjutkan analisis hubungan pengaruh dengan uji koefisien determinasi serta analisis signifikansi pengaruh dengan uji F dan uji t.

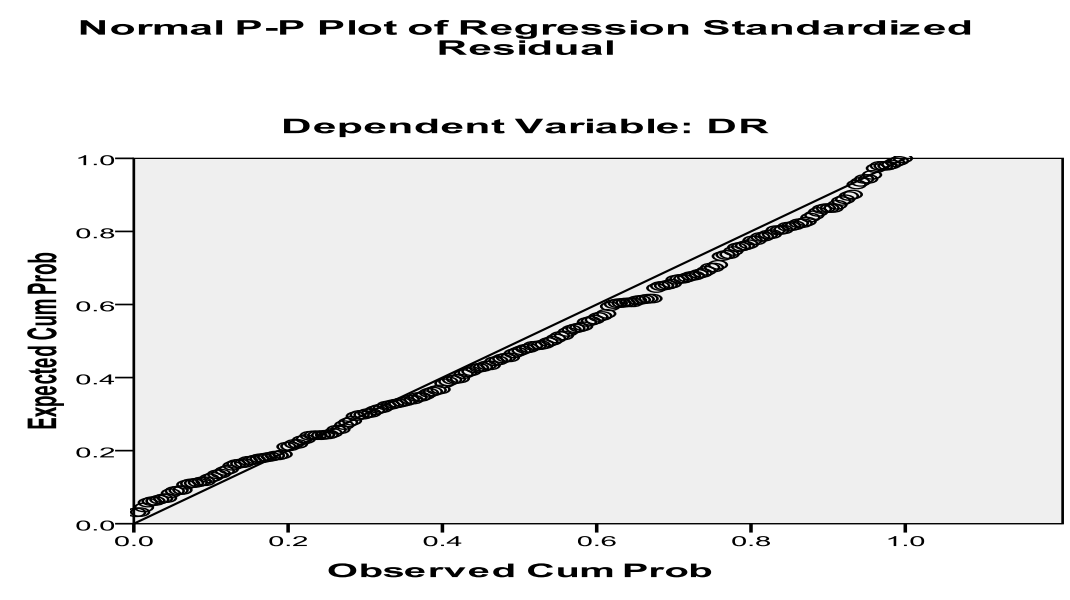

Gambar 2. Hasil Uji Normalitas

Hasil uji normalitas pada Gambar 2 diketahui bahwa data ada di sekitar garis diagonal dan mengikuti arah garis diagonalnya, maka dapat disimpulkan bahwa data memenuhi asumsi normalitas. Hal ini diperkuat dari uji Kolmogorov Smirnov yang disajikan pada Tabel 2.

Tabel 2. One-Sample Kolmogorov-Smirnov Test

\begin{tabular}{llr}
\hline & & \multicolumn{1}{c}{ SRESID } \\
\hline $\mathrm{N}$ & & 200 \\
Normal Parameters $^{\mathrm{a}, \mathrm{b}}$ & Mean & -.000004 \\
& Std. Deviation & 1.0000021 \\
Most Extreme Differences & Absolute & .058 \\
& Positive & .058 \\
& Negative & -.042 \\
Kolmogorov-Smirnov Z & & .815 \\
Asymp. Sig. (2-tailed) & & .520 \\
\hline
\end{tabular}

a. Test distribution is Normal.

b. Calculated from data. 
Hipotesis:

$\mathrm{H}_{0}=$ sampel berdistribusi normal

$\mathrm{H}_{1}=$ sampel tidak berdistribusi normal

Jika Asymp Sig (2-tailed) $>\propto(0,05)$, maka $\mathrm{H}_{0}$ diterima.

Jika Asymp Sig (2-tailed) $<\propto(0,05)$, maka $\mathrm{H}_{0}$ ditolak.

Nilai Asymp Sig (2-tailed) $>\propto(0,05)$, maka $\mathrm{H}_{0}$ diterima sehingga dapat disimpulkan bahwa data berdistribusi normal.

\section{Hasil Uji Multikolinearitas}

Tabel 3. Hasil Uji Multikolinearitas

\begin{tabular}{|c|c|c|c|c|c|c|c|c|}
\hline \multicolumn{9}{|c|}{ Coefficients $^{\mathrm{a}}$} \\
\hline & & \multicolumn{2}{|c|}{$\begin{array}{l}\text { Unstandardized } \\
\text { Coefficients }\end{array}$} & \multirow{2}{*}{$\begin{array}{l}\text { Standardized } \\
\text { Coefficients } \\
\text { Beta }\end{array}$} & \multirow[b]{2}{*}{$\mathrm{t}$} & \multirow[b]{2}{*}{ Sig. } & \multicolumn{2}{|c|}{$\begin{array}{c}\text { Collinearity } \\
\text { Statistics }\end{array}$} \\
\hline \multicolumn{2}{|c|}{ Model } & B & Std. Error & & & & Tolerance & VIF \\
\hline \multirow[t]{4}{*}{1} & (Constant) & -.015 & .125 & & -.120 & .905 & & \\
\hline & PASET & 1.124 & 1.342 & .057 & .838 & .403 & .970 & 1.031 \\
\hline & PROE & .974 & .272 & .246 & 3.585 & .000 & .970 & 1.031 \\
\hline & PQR & -1.006 & .354 & -.194 & -2.843 & .005 & .981 & 1.019 \\
\hline
\end{tabular}

a. Dependent Variable: DR

Dari hasil uji multikolinearitas diketahui pada Tabel 3 bahwa seluruh variable independen mempunyai nilai VIF lebih kecil dari 10. Maka tidak terdapat multikolinearitas pada model regresi yang digunakan.

Hasil Uji Autokorelasi. Pengujian asumsi klasik autokorelasi dilakukan dengan menggunakan pengujian Durbin-Watson. Angka Durbin-Watson yang didapat adalah sebesar 1,813 Setelah disesuaikan dengan nilai tabel maka tidak terjadi autokorelasi.

Tabel 4. Model Summary ${ }^{\mathrm{b}}$

\begin{tabular}{llrrrr}
\hline Model & R & R Square & Adjusted R Square & $\begin{array}{c}\text { Std. Error of the } \\
\text { Estimate }\end{array}$ & Durbin-Watson \\
\hline 1 & $.324^{\mathrm{a}}$ & .105 & .091 & .0716158 & 1.813 \\
\hline
\end{tabular}

a. Predictors: (Constant), PQR, PASET, PROE

b. Dependent Variable: DR

Hasil Uji Heteroskedastisitas. Hasil analisis dengan menggunakan SPSS pada pilihan menu scatterplot adalah sebagai berikut:

Berdasarkan grafik scatter-plot pada Gambar 3, nampak titik-titik tersebar yang berarti tidak mengalami gejala heterokedastisitas. 


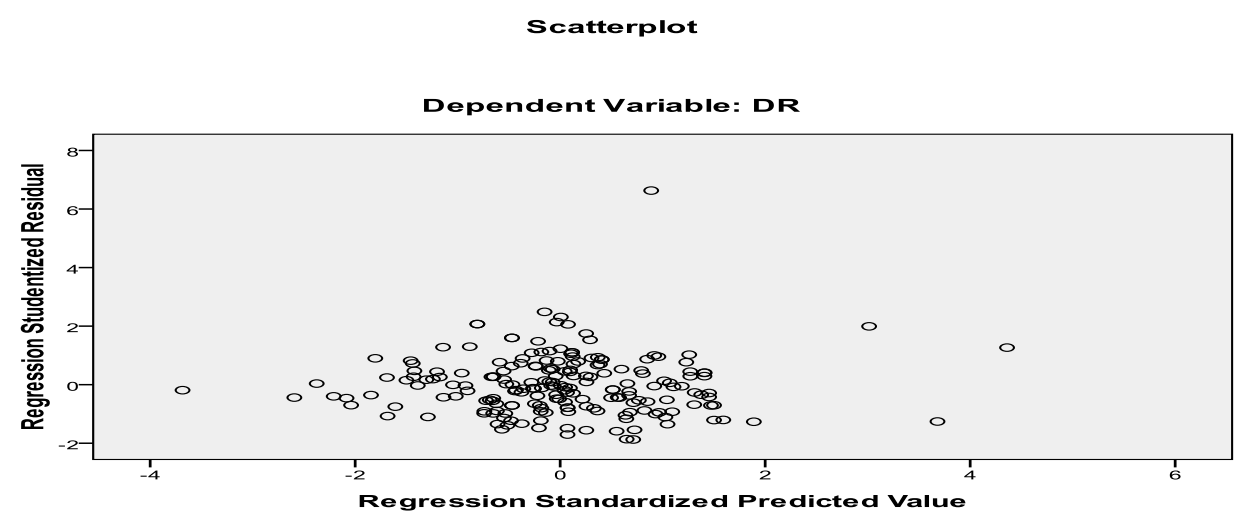

Gambar 3. Scatter Plot

Hasil Uji Goodness of fit

Tabel 5. Hasil Uji F

\begin{tabular}{llrrrrr}
\multicolumn{7}{c}{ ANOVA $^{\mathbf{b}}$} \\
\multicolumn{1}{l}{ Model } & & Sum of Squares & df & Mean Square & F & Sig. \\
\hline 1 & Regression & .118 & 3 & .039 & 7.661 & $.000^{\text {a }}$ \\
& Residual & 1.005 & 196 & .005 & & \\
& Total & 1.123 & 199 & & & \\
\hline
\end{tabular}

a. Predictors: (Constant), PQR, PASET, PROE

b. Dependent Variable: DR

Dari hasil uji $\mathrm{F}$ diatas diketahui bahwa nilai signifikansi $\mathrm{F}$ sebesar $0,000<\alpha_{0,01}$. yang berarti terdapat pengaruh PASET, PROE dan PQR secara bersama-sama terhadap DR.

Hasil Uji t (Pengujian Hipotesa). Untuk menguji hipotesa dilakukan pengujian secara parsial untuk melihat signifikansi dari pengaruh masing-masing variabel independen terhadap variabel dependen dengan mengasumsikan variabel lain adalah konstan. Hasil uji t disajikan pada Tabel 5.

Dasar pengambilan keputusan:

Jika $p$-value $<\alpha_{0,05}$ maka Ho ditolak.

Jika $p$-value $>\alpha_{0,05}$ maka Ho diterima.

Tabel 6. Hasil Uji t (Uji Parsial)

Coefficients $^{\mathrm{a}}$

\begin{tabular}{|c|c|c|c|c|c|c|c|c|}
\hline \multirow{2}{*}{\multicolumn{2}{|c|}{ Model }} & \multicolumn{2}{|c|}{$\begin{array}{l}\text { Unstandardized } \\
\text { Coefficients }\end{array}$} & \multirow{2}{*}{$\begin{array}{c}\begin{array}{c}\text { Standardized } \\
\text { Coefficients }\end{array} \\
\text { Beta }\end{array}$} & \multirow[b]{2}{*}{$\mathrm{t}$} & \multirow[b]{2}{*}{ Sig. } & \multicolumn{2}{|c|}{$\begin{array}{l}\text { Collinearity } \\
\text { Statistics }\end{array}$} \\
\hline & & $\mathrm{B}$ & Std. Error & & & & Tolerance & VIF \\
\hline 1 & (Constant) & -.015 & .125 & & -.120 & .905 & & \\
\hline & PASET & 1.124 & 1.342 & .057 & .838 & .403 & .970 & 1.031 \\
\hline & PROE & .974 & .272 & .246 & 3.585 & .000 & .970 & 1.031 \\
\hline & PQR & -1.006 & .354 & -.194 & -2.843 & .005 & .981 & 1.019 \\
\hline
\end{tabular}

a. Dependent Variable: DR 
Persamaan penelitian sebagai hasil regresi adalah:

$$
\begin{aligned}
\text { DR }= & -0,015+1,124 \mathrm{PASET}+ \\
& (-0,120)(0,974 \mathrm{PROE}-1,006 \mathrm{PQR}+\varepsilon \\
(3,585)^{* * *} & (-2,843)^{* * *}
\end{aligned}
$$

Adjusted $\mathrm{R}^{2}=0.091$

$* * *$ Significant at the 0.01 level

**Significant at the 0.05 level

Pada persamaan hasil regresi menunjukkan pengaruh peningkatan asset (PASET) terhadap debt ratio (DR) bersifat positif . Nilai t-statistik 0,838 dengan nilai probabilitas lebih besar dari $\alpha=0,05$ atau tingkat kepercayaan 95\% menunjukkan bahwa pengaruh peningkatan asset (PASET) terhadap debt ratio (DR) tidak signifikan. Pengaruh peningkatan return on equity (PROE) terhadap debt ratio (DR) positif dan signifikan yaitu terlihat pada nilai t-statistik $=3,585$ dengan nilai probabilitas 0,000 yang lebih kecil dari $\alpha=0,01$ atau tingkat kepercayaan 99\%. Pengaruh peningkatan quick ratio (PQR) terhadap debt ratio (DR) negative dan signifikan yaitu terlihat pada nilai t-statistik = 2,843 dengan nilai probabilitas 0,005 yang lebih kecil dari $\alpha=0,01$ atau tingkat kepercayaan 99\%. Pada persamaan hasil regresi menunjukkan nilai adjusted $\mathrm{R}^{2}$ yaitu 0,091 artinya dengan menggunakan model tersebut debt ratio (DR) perusahaan tidak cukup hanya dijelaskan oleh variabel-variabel bebas peningkatan asset (PASET), peningkatan return on equity (PROE) dan peningkatan quick ratio (PQR).

\section{PENUTUP}

Simpulan. Dari hasil penelitian dapat disimpulkan bahwa: (1) peningkatan asset (PASET) menunjukkan pengaruh yang tidak signifikan terhadap debt ratio (DR) perusahaan sektor perdagangan, jasa dan investasi yang terdaftar di Bursa Efek Indonesia, (2) Terdapat pengaruh peningkatan return on equity (PROE) yang memberikan dampak positif dan signifikan terhadap debt ratio (DR) perusahaan sektor perdagangan, jasa dan investasi, (3) Terdapat pengaruh peningkatan quick ratio (PQR) yang memberikan dampak negatif dan signifikan terhadap debt ratio (DR) perusahaan sektor perdagangan, jasa dan investasi.

Saran. Berdasarkan temuan-temuan dari penelitian ini, bagi para investor saham di Bursa Efek Indonesia khususnya dalam berinvestasi di sektor perdagangan, jasa dan investasi yang terdaftar di Bursa Efek Indonesia. perlu memperhatikan dan mempertimbangkan factor peningkatan return on equity (PROE) dan peningkatan quick ratio (PQR) perusahaan sebelum berinvestasi, karena dari hasil penelitian ini terbukti bahwa peningkatan return on equity (PROE) dan peningkatan quick ratio (PQR) terbukti berpengaruh secara signifikan terhadap debt ratio (DR) perusahaan sektor perdagangan, jasa dan investasi yang terdaftar di Bursa Efek Indonesia.

\section{DAFTAR RUJUKAN}

Ang, Robbert. (1997). Buku Pintar: Pasar Modal Indonesia. Mediasoft Indonesia. Jakarta Brigham, Eugene F. And Houston, Joel F. (2001). Fundamentals of financial management $9^{\text {th }}$ ed. Hartcourt College Publishers, Florida 
Bodie, Z., Kane, Alex dan Marcus, Alan J. (2011). Investment $9^{\text {th }}$ ed. New York: McGraw Hill Companies, Inc.

Cassar, Gavin; Holmes, Scott, (2003). Capital structure and financing of SMEs: Australian evidence, Journal of Accounting \& Finance (ACF), July, p.123.

Damodaran, A., (2001). Corporate Finance: Theory and Practice, $2^{\text {nd }}$ edition, New York, John Willey \& Sons, Inc.

Darsono \& Ashari., (2005). Pedoman Praktis Memahami Laporan Keuangan. Edisi Satu Yogyakarta. Andi Yogyakarta.

Ghozali, Imam, (2005). Aplikasi Analisis Multivariate dengan Program SPSS, BPUniversitas Diponegoro, Semarang.

Gitman, Lawrence J. (2009). Principle of Managerial Finance. $12^{\text {th }}$ edition. Pearson education Addison Wesley, inc. USA: Yale University

Gujarati, Damodar, (2003). Basic Econometric, Mc Graw Hill, USA

Hall, Graham C; Hutchinson, Patrick J; Michaelas, Nicos, (2004). Determinants of the capital structure of European SMEs, Journal of Business Finance \& Accounting (JBF), June, p. 711.

Hanafi., (2005). Analisa Laporan Keuangan. Edisi ke Dua. Yogyakarta. UPP AMP YKPN.

Harahap, Sofyan Syafri. (2004). Teori Akuntansi. Edisi Revisi. Jakarta: PT. Raja Gafindo Persada.

Ikatan Akutansi Indonesia, (2007). Standar Akuntansi Keuangan, Penerbit Salemba Empat, Jakarta

Keown, Arthur J., Martin John D., Petty J. William., dan David F. Scott, JR. (2005). Financial Management, $10^{\text {th }}$ edition . Pearson Prentice Hall.

Mardiyanto, Handoyo. (2009). Intisari Manajemen Keuangan. Penerbit PT Grasindo. Jakarta

Munawir, S., (2001). Analisa Laporan Keuangan. Liberty, Yogyakarta

Nachrowi, Djalal N., dan Hardius Usman, (2002). Penggunaan Teknik Ekonometri, Cetakan pertama, Jakarta: PT RajaGrafindo Persada.

Pandey, M., (2001). Capital Structure and The Firms Characteristics: Evidence From An Emerging Market, India, IIMA Working Paper.

Prabansari, Yuke dan Kusuma, Hadri. (2005). Faktor-faktor yang Mempengaruhi Struktur Modal Perusahaan Manufaktur Go Public di Bursa Efek Jakarta. Sinergi: Kajian Bisnis dan Manajemen, Edisi Khusus on Finance,1-15

Pyndick, S. Robert and Rubinfeld L. Daniel, (1998). Econometric Models Economic Forecast, Fourth Edition, McGraw-Hill International Editions

Rahardjo, Budi, (2003). Laporan Keuangan Perusahaan Membaca, Memahami dan Menganalisis, Gadjah Mada University Press,

Riyanto, Bambang. (1995). Dasar - Dasar Pembelanjaan Perusahaan.Yogyakarta: BPFE Yogyakarta.

Ross, Stephen A., Westerfield, Randolph, W., and Jaffe, Jeffrey, (2005). Corporate Finance, $7^{\text {th }}$ edition. McGraw Hill International.

Santoso, Singgih., (2001). Latihan SPSS Statistik Parametrik, Jakarta: PT. Elex Media Computindo,

Santoso, Singgih, (2004). Buku Latihan SPSS Statistik Multivariat, Elex Media Komputindo.

Sartono, Agus. (2001). Manajemen Keuangan: Teori dan Aplikasi. BPFE. Yogyakarta 
Shapiro, (1992). Modern Corporate Finance, Prentice Hall. USA.

Suharyadi, dan Purwanto S.K., (2004). Statistika untuk Ekonomi dan Keuangan Modern, Buku 2. Penerbit Salemba Empat, Jakarta.

Sundjaja RS., dan Barlian I., (2003). Manajemen Keuangan $5^{\text {th }}$ ed. Literata Linta Media,. Jakarta

Voulgaris, F., Asteriou, D., Agiomirgianakis, G., (2002). Capital Structure, Assets Utilization, Profitability, and Growth in The Greek Manufacturing Sector, Journal of Apllied Economics (APE), 20 (July), p. 1379.

Warren, C.S., Reeve, J.M., \& Fess, P.E., (2005). Accounting $21^{\text {th }}$ ed.. Jakarta: Penerbit Erlangga.

Wild, John J, K. R. Subramanyam and Robert F. Halsey. (2006). Financial statement analysis. $9^{\text {th }}$ edition. Singapore: Mc Graw-Hill 